\title{
Economics of grazing weeping lovegrass with stockers in the Southern Great Plains
}

\author{
L. ALLEN TORELL, REX E. KIRKSEY, GARY B. DONART, AND JAMES D. LIBBIN
}

Authors are professor, Dept. of Agr. Econ. and Agr. Business, New Mexico State University, Las Cruces, N.M. 88003; superintendent, Agricultural Science Center, Tucumcari, N.M. 88401, professor, Department of Animal and Range Sciences, New Mexico State University, Las Cruces, N.M. 88003; and professor, Dept. of Agr. Econ. and Agr. Business, New Mexico State University, Las Cruces, N.M. 88003

\begin{abstract}
Because of the relatively low cost of seed and ease of establishment, more than 0.4 million ha of weeping lovegrass (Eragrostis curvula (Shrad.) Nees.) were planted on Conservation Reserve Program (CRP) lands in the Southern High Plains. Dryland cropping alternatives including wheat and grain sorghum, give relatively low and variable economic returns. The objective of this study was to evaluate the economics of the lovegrass grazing alternative. Using a tract of weeping lovegrass in Curry County, N.M., animal performance and the economics of 5 grazing management treatments were evaluated, including 12-month and 6month continuous grazing, seasonal grazing during only the spring and fall, and a 6-pasture rotation system. Fertilization of the pastures was also evaluated for the spring/fall grazing treatment. Average daily gain (ADG) for yearlings grazing weeping lovegrass pastures was found to decline rapidly as the grazing season progressed. The ADG was over $1.36 \mathrm{~kg} \mathrm{day}^{-1}$ in early May but gradually declined over the grazing season to less than 0.45 kg day ${ }^{-1}$ by the end of August. To maximize profit, stocker cattle would be sold in early September. All of the grazing systems yielded similar net economic returns, but substantially higher economic returns could be made by adjusting stocking rates to market conditions. Returning CRP land to dryland cropping or grazing with stocker cattle was estimated to yield nearly identical economic returns. Neither growing traditional crops or grazing lovegrass pastures appear to be economically viable alternatives without government assistance programs in place.
\end{abstract}

Key Words: Conservation Reserve Program, Eragrostis curvula (Shrad.) Ness., forage quality, optimal stocking rates, dryland farming, grazing systems

One of the highest Conservation Reserve Program (CRP) participation rates in the nation was found in Eastern New Mexico and West Texas. Nearly one-fourth the cropland acreage in this region was planted to perennial grasses as a result of the CRP, a voluntary long-term cropland retirement program. Dryland farming in the area is risky with variable and limited profit potential. As reported by the New Mexico State University (NMSU) crop

Research was supported in part by a USDA SARE grant and the New Mexico Agricultural Experiment Station, New Mexico State University, Las Cruces. The authors thank Hildagard Van Voorthuizen and Scott Bailey for assistance in statistical analyses.

Manuscript accepted 6 Sept. 1999.

\section{Resumen}

Debido a su habilidad de establecimiento y al bajo costo de la semilla, aproximadamente, 400,000 ha de Weeping Lovegrass (Eragrostis curvula (Shrad.) Ness.) fueron cultivadas en los terrenos del Conservation Reserve Program (CRP) en la planicie del Sur. En adición, cultivos como el Trigo y el Sorgo en zonas semidesérticas son asociados con pobres ganancias y tasas de retorno bajas. El objetivo fue evaluar la viabilidad económica del uso de Lovegrass en condiciones pastoreo con bovinos en Curry County, N.M. Los tratamientos fueron: 1)Pastoreo Continuo por 12 meses, 2) Pastoreo continuo por seis meses, 3) Pastoreo en Otoño, 4) Pastoreo en Primavera, y 5) Sistema rotacional de seis días. La ganancia de peso de los bovinos por día (GDP) pastoreando Weeping Lovegrass disminuyó radpidamente conforme avanzó la estación de pastoreo. La ganancia de peso fue $\mathbf{1 . 3 6}$ $\mathrm{Kg}$ /día a principios de Mayo y disminuyó gradualmente hasta .45 $\mathrm{Kg} /$ día a finales de Agosto. Para maximizar las ganacias los becerros destetados fueron vendidos a principios de Septiembre. Todos los sistemas de pastoreo produjeron retornos econlmicos similares. Sin embargo, la rentabilidad financiera pudiera incrementarse ajustando la carga animal a las condiciones del mercado. Retornos económicos similares fueron observados con cultivos de secano o pastoreo de bovinos en el CRP. El cultivo tradicional de granos y el pastoreo de Lovegrass con bovinos parecen ser sistemas de producción poco rentables sin el apoyo de programas de cooperación técnica del Estado.

cost and return series (Hawkes and Libbin 1997a, 1997b), return to land and risk was negative in 7 of the most recent 13 years in Quay County and 4 of 13 years in Curry County. With average New Mexico CRP program payments of \$94 ha ${ }^{-1}$ (Osborn et al. 1995) many area farmers believed the CRP was a more profitable alternative and signed up for the program in the early years.

Because of its relatively low seeding cost and ease of establishment, weeping lovegrass (Eragrostis curvula (Shrad.) Nees.) was one of the most prevalent grass species planted on CRP land in the Southern Great Plains. It is a long-lived perennial bunchgrass that grows and produces well on a wide variety of soils. Lovegrass is an excellent soil stabilizer and is drought tolerant. But, weeping lovegrass is generally considered to be a poor forage for grazing livestock.

Under new guidelines and requirements for CRP participation (USDA-FSA 1997), many individuals who planted monocultures of weeping lovegrass, especially those with a tighter less erodible soil, were not renewed into the continuing CRP program (person- 
al communication Richard Shaw, USDANRCS, Clovis, N.M. Field Office, 18 August 1998). These producers must now decide the future use of their lands, and other CRP enrollees will eventually face similar decisions. A primary factor in this decision will be the relative productivity and profitability of using these lands for grazing versus converting back to crop production. The objective of this study was to evaluate the performance of stocker calves grazing weeping lovegrass under different management strategies. The economics of alternative grazing systems for lovegrass pastures are compared to traditional cropping alternatives.

\section{Materials and Methods}

\section{Theoretical Grazing Concepts}

As shown by Hildreth and Riewe (1963), Workman (1986) and Hart et al. (1988), determining the economically optimal (profit maximizing) grazing strategy means selecting the stocking rate and grazing system that maximizes net economic returns per ha for the defined price/cost situation. Defining this optimal grazing strategy requires definition of expected beef prices and costs over the planning period. It also requires definition of relevant biological input/output relationships using the production function. In defining the production function we use the standard definition of stocking rate to relate the total demand for forage to the area used to provide it. Stocking rate (SR) is defined to be the number of stocker cattle grazing per ha over a grazing period of length T (Vallentine 1990) ${ }^{1}$.

In addition to the standard analysis of how SR affects animal performance and profit, an additional consideration is how declining forage quality affects livestock production and profitability. This would be especially important for a plant like weeping lovegrass where forage quality deteriorates quickly over the grazing season. Yet, few economic studies have considered forage quality when making man-

\footnotetext{
${ }^{1}$ The budget and design of the grazing trials conducted here did not allow us to compare net returns at altnerative stocking rates (SR, i.e., animals $\mathrm{ha}^{-1}$, animal days of grazing ha ${ }^{1}$ ) or grazing pressures (GP, i.e., animal or head days of grazing per unit of herbage produced). The economic model used to evaluate optimal grazing strategies is the same, however, with or without variation in stocking rate. In the more limited applications where SR is not a choice variable, grazing systems can only be compared at the rates used in the grazing trial.
}

agement prescriptions. Huffaker and Wilen (1991) found that when nutrient deterioration of tall fescue pastures in Tennessee was high, an intensive early grazing strategy (IES) that doubled the conventional season-long stocking rate early and then rested the pasture with no stocking as forage nutrients began to play out would be economically optimal. If the grass cultivar exhibited low nutrient deterioration over the season then the conventional season-long grazing strategy outperformed the IES.

To consider both stocking rate and deterioration of forage quality over the grazing season, average daily gain (ADG) cannot be defined in the typical way, with an average rate of gain for the grazing season assumed, or with ADG considered to be a function of SR only (Workman 1986). Rather, diminished livestock gain must be explicitly recognized. There are at least 2 alternative ways to do this. First, the strategy used by Huffaker and Wilen (1991) can be employed with grazing animals allocated between pasture grazing and the next best feeding alternative. Depending on pasture production and forage quality, cattle are allocated between alternative feed sources so as to maximize profit. The second alternative, as used here, is to stock the pasture with animals at the start of the grazing season. All animals are then removed at some point once forage quality has deteriorated to an unacceptable level, or when a threshold amount of forage remains. Cattle could be sold at this point or they could be moved to alternative pastures or feedlots. Stocking rate of the pasture is a choice variable in the model and with adequate data to define input/output relationships the stocking rate used could be an economically optimal rate.

To develop the economic model, let average daily gain (ADG) be defined as a concave function of stocking rate (SR) and time of year $(\mathrm{t})$, with deteriorating forage quality $(\mathrm{Q})$ the factor reducing $\mathrm{ADG}$ over time.

$$
\mathrm{ADG}=\mathrm{f}(\mathrm{SR}, \mathrm{Q}(\mathrm{t}))
$$

with $\partial \mathrm{f} / \partial \mathrm{SR}<0, \partial \mathrm{f} / \partial \mathrm{Q}>0$ and $\partial \mathrm{Q} / \partial \mathrm{t}<0$ over the economically relevant range of production. Time (t) could also be used as a direct proxy for forage quality if recognition is given to the importance that forage quality has it determining livestock performance at different points in time. The time variable defines the day of the grazing season, either as the Julian date or as the elapsed number of days that stocker cattle have been in the pasture.

The total $\mathrm{kg}$ of beef sold per ha is defined by multiplying the number of ani- mals grazing per ha times the average sale weight (Ws), less a market shrink:

$$
\mathrm{b}(\mathrm{SR}, \mathrm{T})=\mathrm{SR} \times \mathrm{W}_{\mathrm{S}} \times\left(1-\frac{\% \text { Shrink }}{100}\right) \text { (2) }
$$

The sale weight, given by $\mathrm{W}_{\mathrm{s}}=\left[\mathrm{W}_{\mathrm{p}}+\int_{\mathrm{t}=1}^{\mathrm{T}}\right.$ $\mathrm{f}(\mathrm{SR}, \mathrm{Q}(\mathrm{t})) \mathrm{dt}]$, is determined by the stocking rate decision. Increasing stocking rates will decrease ADG and sale weight, but except in the extreme, more beef will be produced per ha. Average sale weight will also depend on purchase weight $\left(\mathrm{W}_{\mathrm{p}}\right)$ and the decision about when to market the cattle (i.e., the selection of sale period (T)). As the length of time cattle remain in the pasture is extended there will be a continued decrease in ADG because of declining forage quality.

Heavier feeder cattle generally sell for less per kg (Sartwelle et al. 1995). While sale price is determined by market forces outside the livestock producer's control, the producer determines which market price to accept by the size and type of cattle produced. Size of cattle depends on stocking rate and marketing decisions, such that in addition to market forces, sale price $\left(\mathrm{P}_{\mathrm{S}}\right)$ is a function of $\mathrm{SR}$, sale date and livestock characteristics;

$$
\mathrm{Px}=\mathrm{g}\left(\mathrm{W}_{\mathrm{S}}(\mathrm{SR}, \mathrm{T}), \mathrm{X}\right)
$$

where $\mathrm{X}$ is a vector of exogenous variables that identify relevant characteristics of the stockers at time of sale (e.g., breed, frame size, health, fill, sex, muscling).

The livestock producer selling in the competitive market is faced with the problem of choosing the stocking rate and sale date that maximizes profit, with profit defined to be the residual return to land and risk (\$/ha):

$$
\begin{aligned}
& \pi(\mathrm{SR}, \mathrm{T})=\mathrm{g}\left(\mathrm{W}_{\mathrm{s}}(\mathrm{SR}, \mathrm{T}), \mathrm{X}\right) \mathrm{xb}(\mathrm{SR}, \mathrm{T})- \\
& \mathrm{SR}\left[\left(\mathrm{P}_{\mathrm{p}} \mathrm{W}_{\mathrm{p}}+\mathrm{r}\right)+\int_{\mathrm{t}=1}^{\mathrm{T}} \mathrm{C}(\mathrm{t}) \mathrm{dt}\right]-\mathrm{a}
\end{aligned}
$$

where $P_{p}$ is stocker purchase price $(\$ / \mathrm{kg})$, $\mathrm{P}_{\mathrm{p}} \mathrm{W}_{\mathrm{p}}$ is per head animal purchase cost, and $\mathrm{r}$ is additional per head costs of receiving the cattle, including shipping, vaccinations, labor, and other miscellaneous charges. In addition to receiving costs (r) and fixed costs (a), there are additional daily costs $[\mathrm{C}(\mathrm{t})]$ to keep the stocker cattle in the pasture, like periodic checking of animals, supplemental feeds, salt, minerals, and a pasture charge (if the forage is leased on a per-head basis by the month). This daily cost may be different at different times of the year because of weather or pasture conditions. Further, pasture charges could be calculated on a cost per $\mathrm{kg}$ of gain. In this case, accumulated daily 
costs would be defined as $\int_{\mathrm{T}=1}^{\mathrm{T}} \mathrm{C}(\mathrm{f}(\mathrm{SR}, \mathrm{Q}(\mathrm{t})$ and would add the complication that because average daily gain (ADG) declines with falling forage quality, grazing costs decrease as forage quality deteriorates over the grazing season.

Following the well known marginal principles of production economics, the profit maximizing stocking rate will occur when the last animal added to the pasture adds nothing to profit (Workman 1986). Similarly, the optimal time to sell the animals will occur when the value of the additional animal gain from keeping the animals another day is just equal to the marginal costs of keeping the animals that extra day. The economically optimal stocking rate and sale date will change as economic and pasture conditions change. See Torell et al. (1999) for a more detailed discussion of how economically optimal management strategies would be determined when declining forage quality is an important consideration.

\section{Grazing Trials}

A tract of weeping lovegrass in Curry County, N.M. that had been enrolled in the CRP was developed for a grazing trial in spring 1994. The tract site is approximately $24 \mathrm{~km}$ north of Clovis, N.M. on the Wayne Palla Farm. Soils are Pullman and Mansker loams. Mean annual precipitation in the area is $44 \mathrm{~cm}$ (NOAA Various issues).

From the time the weeping lovegrass cover was established in 1987, until spring 1994, the tract received no cultural management operations, except for a single mowing in 1988 to reduce competition from annual forbs. The entire tract was subjected to a controlled burn on 13 April 1994 to renovate the decadent grass stand. A 146 ha portion of the tract was selected for use as a grazing trial and was developed with a livestock watering system and cross-fenced with hi-tensile electric fencing.

The grazing area was divided into 10 pastures which consisted of 2 replications of 5 grazing management treatments: 1) 12-month continuous grazing (12-Mo), 2) 6-month continuous grazing (6-Mo), 3) grazing only during the spring and fall (S/F), 4) spring/fall grazing with fertilizer application (S/F w/F), and 5) a 6-pasture rotation scheme (Rot). The 12-Mo pastures were 24 ha in size, all others were 12 ha. Thus, for the continuous grazing treatments, grazing pressure was held constant by adjusting the acreage to accommodate the longer grazing season. The location of the individual grazing treatments did not change during the 3-year study period.

The 12-Mo treatment consisted of year- round use of the available forage while the other treatments consisted of grazing during the spring, summer and fall months only. The planned objective of the continuous grazing treatments (12-Mo and 6Mo) was to use a nearly constant stock density so as to fully utilize all available forage during the predetermined grazing period.

During the early part of the growing season (spring), stock density for the spring/fall grazing treatments ( $\mathrm{S} / \mathrm{F}$ and $\mathrm{S} / \mathrm{F}$ w/F) was set at a high enough rate to utilize all available forage by mid- to late July. These pastures were then allowed to regrow for 3 to 4 weeks during the summer without grazing pressure. During this 3 to 4 week regrowth period, stocker cattle grazed an adjacent pasture of weeping lovegrass. For the S/F and S/F w/F treatments during the fall the stock density was set at one-half the rate used during the spring grazing period. The $\mathrm{S} / \mathrm{F}$ w/F pastures received a broadcast application of urea fertilizer prior to the initiation of grazing each year. Application dates and rates were as follows: 3 June 1994, $38 \mathrm{~kg}$ ha $^{-1} \mathrm{~N}$; 18 April 1995, $43 \mathrm{~kg} \mathrm{ha}^{-1} \mathrm{~N}$; 9 July 1996, $50 \mathrm{~kg} \mathrm{ha}^{-1} \mathrm{~N}$. As shown in Table 1, only minimal differences in stocking rates occurred between the fertilized and unfertilized S/F treatments, but there was unused forage at the end of the season on fertilized areas. Stocking rates could have been increased or the grazing season extended during the spring or fall period with fertilizer application.

\begin{tabular}{|c|c|c|c|c|}
\hline Treatment & Treatment Description & Year & Dates Grazed & Stocking Rate \\
\hline & & & & (head/ha) \\
\hline \multirow[t]{2}{*}{ 12-Mo } & \multirow[t]{2}{*}{12 Month Continuous } & 1994 & 15 Jun. - 26 Jul. & 0.412 \\
\hline & & 1995 & 9 May - 21 May & 0.450 \\
\hline \multirow[t]{3}{*}{ 6-Mo } & \multirow[t]{3}{*}{6 Month Continuous } & 1994 & 15 Jun. - 29 Nov. & 0.823 \\
\hline & & 1995 & 9 May - 16 Nov. & 0.914 \\
\hline & & 1996 & 4 Jun. - 14 Nov. & 0.914 \\
\hline \multirow[t]{3}{*}{$\mathrm{S} / \mathrm{F}$} & \multirow[t]{3}{*}{ Spring/Fall } & 1994 & $\begin{array}{l}15 \text { Jun. - } 27 \text { Jul. } \\
7 \text { Sep. - } 29 \text { Nov. }\end{array}$ & $\begin{array}{l}1.647 \\
0.914\end{array}$ \\
\hline & & 1995 & $\begin{array}{l}9 \text { May - } 26 \text { Jul. } \\
23 \text { Aug. - } 16 \text { Nov. }\end{array}$ & $\begin{array}{l}1.763 \\
0.914\end{array}$ \\
\hline & & 1996 & $\begin{array}{l}4 \text { Jun. - } 23 \text { Jul. } \\
20 \text { Aug. - } 14 \text { Nov. }\end{array}$ & $\begin{array}{l}1.763 \\
0.951\end{array}$ \\
\hline \multirow[t]{3}{*}{$\mathrm{S} / \mathrm{F}$ w/F } & \multirow[t]{3}{*}{ Spring/Fall with Fertilizer } & 1994 & $\begin{array}{l}15 \text { Jun. - } 27 \text { Jul. } \\
7 \text { Sep. - } 29 \text { Nov. }\end{array}$ & $\begin{array}{l}1.647 \\
1.074\end{array}$ \\
\hline & & 1995 & $\begin{array}{l}9 \text { May - } 26 \text { Jul. } \\
23 \text { Aug. - } 16 \text { Nov. }\end{array}$ & $\begin{array}{l}1.763 \\
0.914\end{array}$ \\
\hline & & 1996 & $\begin{array}{l}4 \text { Jun. - } 23 \text { Jul. } \\
20 \text { Aug. - } 14 \text { Nov. }\end{array}$ & $\begin{array}{l}2.058 \\
0.988\end{array}$ \\
\hline \multirow[t]{3}{*}{ Rot } & \multirow[t]{3}{*}{ 6-Pasture Rotation } & 1994 & 15 Jun. - 29 Nov. & 0.823 \\
\hline & & 1995 & 9 May - 17 Oct. & 1.299 \\
\hline & & 1996 & 4 Jun. - 14 Nov. & 1.235 \\
\hline
\end{tabular}

The pastures utilized for the rotational grazing treatment were subdivided into 6 paddocks. In 1994, individual paddocks were grazed for a 21-day period. After all paddocks had been grazed once (by 19 October) the cattle were provided free access to the entire pasture. Individual paddocks were grazed for 3 to 7 days per rotation cycle in 1995. This shortened grazing cycle was used because the longer rotation did not result in adequate livestock performance and management adjustments were made during subsequent years. Due to the lack of available forage during the early part of 1996, the rotation grazing sequence was not initiated until 12 July. After that date, individual paddocks were grazed for 2 to 4 days each rotation cycle.

Pastures in the grazing study were burned in early April 1995 to even out differences in forage availability created by the 1994 grazing treatments. Many of the pastures did not burn completely, as there was insufficient fuel to carry the fire.

On 15 June 1994, 140 head of yearling crossbred heifers (average body weight $228 \mathrm{~kg}$ ) were delivered to the grazing trial. The heifers which had been preconditioned in a lot at Dalhart, Tex., were sorted randomly into 10 uniform groups and placed on the individual grazing treatments. From 15 June to 9 November 1994 there was no supplemental feeding. From 9 November to 29 November cattle remaining for the continuous grazing treatment received a $37 \%$ protein block supplement (HI-PRO \#1406, HI-PRO feeds, Friona, Tex.) at the rate of $0.5 \mathrm{~kg} \mathrm{head}^{-1}$

\section{Table 1. Stocking rates of the CRP grazing trials, 1994-96.}


day $^{-1}$. From 29 November to 4 April 1995, heifers on the 12-Mo treatment received the equivalent of $0.86 \mathrm{~kg}$ of $37 \%$ protein block day ${ }^{-1}$.

One-hundred eighty steers for the 1995 grazing trial were received from NMSU's Clayton Livestock Research Center (CLRC) on 9 May (average body weight $207 \mathrm{~kg}$ ). One-half of the steers had been backgrounded on winter wheat; the other half had been backgrounded in a feedlot. Within each background group, steers were sorted randomly into 10 groups (grazing treatments). Supplemental feeding began on 5 December 1995. From that date until 22 January 1996, steers on the 12-Mo treatment received a $37 \%$ protein block supplement at a rate of $1 \mathrm{~kg}^{-h^{-1}}$ day $^{-1}$. From 22 January until the steers were removed from the $12-$ Mo treatment on 1 May 1996, the rate of supplementation was $1.18 \mathrm{~kg} \mathrm{day}^{-1}$.

On 4 June 1996, 196 yearling steers of mixed breeding (average body weight 237 $\mathrm{kg}$ ) were received at the grazing trial from the CLRC. As in 1995, one-half the steers came from a feedlot background; the other half came from winter wheat pasture. Steers from each background group were sorted randomly into the grazing treatments. The 12-Mo treatment was not included during 1996. Consequently, there was no supplemental feeding during the 1996 grazing season.

Animal body weights were recorded at 21-day intervals in 1994 and at 28-day intervals in 1995 and 1996, except during the winter months. Body weights for the heifers and steers on the 12-Mo treatment were not recorded at regular intervals once the cattle were removed from the other treatment groups. They were weighed again before sale in the spring.

At all times during the grazing trial, cattle were provided free access to white salt and 12:12 (Ca:P) mineral block (HI-PRO \#1406, HI-PRO feeds, Friona, Tex.). The supplemental feeding of protein blocks was done 3 times per week.

In this analysis, an economic comparison is only made between grazing treatments at or near the level stocked in the grazing trials. Although the economic model has been developed to evaluate optimal stocking rates, SR is not a choice variable in this application. The stocking rates used for each treatment may or may not be an optimal rate for the defined price/cost situation. However, with the exception of the $\mathrm{S} / \mathrm{F} \mathrm{w} / \mathrm{F}$ treatment, by the end of the grazing period, the weeping lovegrass pastures had little unused forage. A greatly increased stocking rate would not have been possible.

\section{Grazing Data Statistical Analysis}

Animal weights, recorded periodically throughout the grazing season, were used to evaluate animal performance under the various grazing treatments and at alternative times during the grazing season. Average daily gain was the key measure of production estimated by the grazing trial data. Other measures of animal performance including gain per ha, animal weights, and total beef production per ha were algebraically determined from the estimated average daily gain (ADG) function for the given stocking rate. The ADG at time $t$ was computed for each animal by dividing the change in weight between weigh periods by the number of days between each weigh period. The mid-point between weigh dates was used to define the point in time of the calculation.

The computed ADG was used for regression analysis to estimate how ADG varied throughout the grazing season for the alternative grazing systems. Because stocking rate was not a variable considered in the grazing trials, SR was not included when estimating the ADG functions. Time was defined to be the number of days past 1 May (i.e. 15 May = 14, 31 July =91). Dummy variables were also used to test for significant differences in ADG between years, between seasons, for the type of backgrounding used, and for fertilized versus unfertilized treatments. Only variables that were significant at the $\alpha=0.10$ level were included in the final equations.

\section{Economic Model Specification}

Economic comparisons were made between stocker cattle grazing CRP land and representative dryland crops typically grown in Curry County and eastern Quay County, as reported in the NMSU crop cost and return estimate series. These comparisons were made for all years that the series had been published, 1984-96. Annual differences in beef price situations were used to compute a return to land and risk $(\mathrm{RLR})^{2}\left(\$ \mathrm{ha}^{-1}\right)$ that could be compared to returns from traditional crop production alternatives.

Historically reported whole-farm RLR estimates were adjusted to constant 1996 real price levels using the unadjusted CPI for all urban consumers. Because variation

\footnotetext{
${ }^{2}$ Return to land and risk is the residual return on the investment in the land, and for accepting the risk of the investment. All other production expenses and opportunity costs have been subtracted, including a return for management and operator labor, and for investments in cattle, crops, and machinery.
}

in prices and yields were explicitly considered in the annual crop cost and return series (Hawkes and Libbin 1997a, 1997b) both price and production risk were considered.

Crop subsidy payments are gradually being phased out (USDA-ERS 1996) and thus were not included in the net return comparison for future land use decisions. Government payments reported in the historical crop cost and return series were removed for this comparison.

In the beef production analysis, only the annual purchase price and sale price of beef were varied. Receiving costs, daily expenses, and overhead expenses, as further defined, remained unchanged at a level appropriate for the 1996-97 production years. The ADG and beef production per ha were defined by the estimated regression equations without a stochastic element. Thus, the stocker production analysis included only price risk. This is justified somewhat by the results of the 3year grazing trial. For predicting ADG of all animals in the pasture, the $95 \%$ confidence interval for mean daily gain was relatively narrow (less than $0.05 \mathrm{~kg} \mathrm{day}^{-1}$ for all grazing treatments until late in the fall). Thus, the results of the grazing trials indicated that the mean ADG of grazing animals would be accurately estimated by the ADG function with a narrow confidence interval. The confidence interval for any one individual animal would of course be much wider.

The beef price models developed by Sartwelle et al. (1995, 1996a, 1996b) were used to relate purchase and selling price of calves and feeder steers to their weight (w). A reduced form of the Sartwelle et al. (1995) regression model that included only sale weight as the explanatory variable was used. By excluding other explanatory variables in the Sartwelle regression models, including lot size, health, breed, condition, and others, the assumption was made that the average effect of these other factors would be captured in the base price defined for the Clovis, N.M. market (Table 2). Purchase price $\left(\mathrm{P}_{\mathrm{p}}\right)$ was based on $204 \mathrm{~kg}$ calves and sale price $\left(\mathrm{P}_{\mathrm{S}}\right)$ on $295 \mathrm{~kg}$ feeder steers. A $3 \%$ sale shrink was assumed at the time of sale. The reduced beef price equations were defined as:

$$
\begin{aligned}
& \mathrm{P}_{\mathrm{p}}=\text { Base }_{\mathrm{c}}-1.77 \times 10^{-3}(\mathrm{w}-204)^{2} \\
& -1.46 \times 10^{-6}\left(\mathrm{w}^{2}-204^{2}\right) \\
& \mathrm{P}_{\mathrm{S}}=\text { Base }_{\mathrm{f}}-7.29 \times 10^{-5}(\mathrm{w}-295)- \\
& 7.29 \times 10^{-7}\left(\mathrm{w}^{2}-295^{2}\right)
\end{aligned}
$$

Considering the 1995 average calf price (Basec) at the Clovis, N.M. market of 
Table 2. Clovis, N.M. auction beef prices and weight adjusted purchase price (Pp), 1984-96.

\begin{tabular}{|c|c|c|c|c|}
\hline Year & $\begin{array}{c}\text { April } \\
\text { Clovis Price } \\
(181-227 \mathrm{~kg})^{\mathrm{a}}\end{array}$ & $\begin{array}{c}\mathrm{P}_{\mathrm{p}} \text { in } \\
\text { equation } 6 \mathrm{a}^{\mathrm{b}}\end{array}$ & $\begin{array}{l}\text { Aug. - Sept. } \\
\text { Clovis Price } \\
(272-318 \mathrm{~kg})^{\mathrm{c}}\end{array}$ & $\begin{array}{c}\text { Buy/Sell } \\
\text { Price } \\
\text { Differential }^{\mathrm{d}}\end{array}$ \\
\hline & \multicolumn{4}{|c|}{ 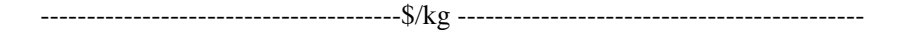 } \\
\hline 1984 & 1.63 & 1.57 & 1.37 & 0.26 \\
\hline 1985 & 1.76 & 1.70 & 1.28 & 0.48 \\
\hline 1986 & 1.52 & 1.46 & 1.37 & 0.15 \\
\hline 1987 & 1.94 & 1.87 & 1.70 & 0.24 \\
\hline 1988 & 2.36 & 2.29 & 1.79 & 0.57 \\
\hline 1989 & 2.27 & 2.20 & 1.90 & 0.37 \\
\hline 1990 & 2.38 & 2.31 & 2.01 & 0.37 \\
\hline 1991 & 2.60 & 2.54 & 1.83 & 0.77 \\
\hline 1992 & 2.25 & 2.18 & 1.83 & 0.42 \\
\hline 1993 & 2.29 & 2.23 & 1.94 & 0.35 \\
\hline 1994 & 2.29 & 2.23 & 1.70 & 0.59 \\
\hline 1995 & 1.92 & 1.86 & 1.39 & 0.53 \\
\hline 1996 & 1.37 & 1.30 & 1.17 & 0.20 \\
\hline
\end{tabular}

${ }^{a}$ Average monthly Clovis auction price reported for April and used to set base ${ }^{c}$ for stocker purchase prices in the Sartwelle price model (Equation 6a).

${ }^{b}$ Purchase price estimated for a $227 \mathrm{~kg}$ steer calf using the average April Clovis, N.M. price as the base.

${ }^{c}$ Average monthly Clovis, N.M. auction price reported for August and September. These prices were used to set base ${ }^{\mathrm{f}}$ for stocker sale prices in the Sartwelle price model (equation $6 b$ ). Estimated sale prices will be different for different grazing systems, sale weights and sale dates.

${ }^{\mathrm{g}}$ Difference between April 181-227 kg calf price and August/September 272-318 kg feeder steer price.

$\$ 1.92 \mathrm{~kg}^{-1}$ (Table 2), with a $227 \mathrm{~kg}$ animal purchased, the adjusted purchase price, using equation $6 \mathrm{a}$, would be $\$ 1.86 \mathrm{~kg}^{-1}$. Using equation $6 \mathrm{~b}$, the computed sale price in the fall will be slightly less than the $\$ 1.39 \mathrm{~kg}^{-1}$ feeder cattle base price (Base $_{\mathrm{f}}$ ) used in the analysis, depending on the sale date and sale weight.

Production expenses were estimated by considering the inputs necessary for the grazing trials, from published NMSU cost and return estimates for yearling producers in northeast New Mexico (Torell et al. 1998), and from dryland crop cost and return estimates prepared for Curry and Quay counties in eastern New Mexico (Hawkes and Libbin 1997b). It was estimated that in addition to the purchase of stocker calves $\left(\mathrm{P}_{\mathrm{p}} \mathrm{W}_{\mathrm{p}}\right)$, a livestock producer could expect to spend about $\$ 11$ head $^{-1}$ for vaccinations, transportation and labor to receive the cattle (r). The daily expense $[\mathrm{C}(\mathrm{t})]$ of checking and caring for the cattle was estimated to be $\$ 0.18$ head $^{-1}$ day $^{-1}$ during the summer months, or about $\$ 32$ head $^{-1}$ for a 180 -day grazing season. This would include labor, salt and minerals, and other miscellaneous expenses. During the winter months $\mathrm{C}(\mathrm{t})$ was estimated to more than double to $\$ 0.47$ head $^{-1}$ day $^{-1}$ because supplemental feeds must be fed [assumed $0.91 \mathrm{~kg} \mathrm{head}^{-1} \mathrm{day}^{-1}$ of cottonseed cake] and labor requirements are increased. An interest charge of approximately $\$ 0.12$ day $^{-1}$ was also added to $\mathrm{C}(\mathrm{t})$. This interest charge was calculated using a $9 \%$ annual interest rate $(0.0247 \%$ daily rate) and was charged each day on the estimated market value of the animal at that point.
Hawkes and Libbin (1997b) estimate overhead expenses to be about $\$ 34.50$ per planted ha (excluding roads and homestead) for a typical 648 ha dryland farm in Curry County, N.M. and this same overhead expense was included for grazing options considered here. Overhead expenses include electricity, telephone, vehicle mileage, insurance, taxes, building repair and maintenance, and other miscellaneous expenses not associated with any specific crop or livestock enterprise. A management charge of $8.5 \%$ of gross livestock sales less purchased livestock and feed expenses was also included as a fixed expense item (Torell et al. 1998).

Weeping lovegrass pastures must be fenced and watered for grazing; a fixed charge for this was included as well. Fence costs were estimated with a 3-wire electric perimeter fence $\left(\$ 884 \mathrm{~km}^{-1}\right)$ and 2-wire electric cross fencing $\left(\$ 720 \mathrm{~km}^{-1}\right)$ for the 6-pasture rotation system, using USDA-NRCS statewide average costs (personal communication Joe Whitehead, USDA-NRCS, Clovis, N.M. Field Office, 18 August 1998). Assuming a square perimeter fence and a 10-year life, annual fence and water costs were estimated to be $\$ 3.71 \mathrm{ha}^{-1}$ for the 6-pasture rotation system with cross fencing, and $\$ 2.47 \mathrm{ha}^{-1}$ for other grazing systems that need only a perimeter fence.

Fertilizer application of about $45 \mathrm{~kg} \mathrm{ha}^{-1}$ $\mathrm{N}$ was applied to the $\mathrm{S} / \mathrm{F}$ w/F at an approximate cost of $\$ 20.50 \mathrm{ha}^{-1}$ with custom application. This amount was included as part of the fixed expense for the $\mathrm{S} / \mathrm{F}$ w/F treatment.
It was assumed in the economic analysis that $227 \mathrm{~kg}$ steer calves would be purchased. Grazing dates used in the economic models were similar to those used in the grazing trials. They were different depending on the grazing system. For all grazing systems the assumed date when stockers entered the pasture was 1 May. The optimal sale date was calculated by the economic model for the continuous and 6pasture rotation systems. For continuous grazing, stocking rate (SR) was set at 0.91 steers $\mathrm{ha}^{-1}$ and all animals remained in the pasture until the economically optimal sale date. For rotational grazing the stocking rate was increased to 1.24 steers $^{-1}$.

Numerous marketing strategies are possible for the spring/fall (S/F) grazing treatment. First, following the strategy used in the grazing trials, stocker cattle could be grazed during both the spring and fall periods. This would require additional land for grazing when cattle are not on the treatment area or when SR is reduced on the pastures during the fall. In this case it was assumed that animals would graze the S/F treatment area from 1 May until 25 July at a stocking rate of 1.76 steers ha ${ }^{-1}$. Over this period, animals are assumed to gain at the rates estimated by the S/F ADG function with the dummy variable DFALL $=0$. Stockers are then moved to a different ungrazed weeping lovegrass pasture and stocked at the rate of the continuous grazing strategy. During this continuous grazing period, yearlings are assumed to gain at the rates defined by the continuous grazing average daily gain (ADG) function. Half of the stockers remain in the continuous grazing pasture and half of the animals are returned to the $\mathrm{S} / \mathrm{F}$ treatment area on 27 August.

Different ADG functions are then used for the 2 groups of cattle and the fall dummy variable is set to one to reflect the fall season. Over the grazing season, a total of 0.81 ha would be needed to support the 1.76 steers $^{-1} \mathrm{a}^{-1}$ initially stocked on the $\mathrm{S} / \mathrm{F}$ treatment area. The stocking allowance for the total grazing season is then 1.14 ha steer $^{-1}\left(\mathrm{SR}=0.88\right.$ steers ha $\left.{ }^{-1}\right)$.

As a second marketing strategy, the $\mathrm{S} / \mathrm{F}$ grazing area could be stocked during the spring at the relatively heavy rate of 1.76 steers $\mathrm{ha}^{-1}$ (as was done in the grazing trials). Animals could then be sold as they exited the S/F grazing area on 25 July. The important difference between S/F marketing alternatives is that additional land was allotted when the grazing season was extended to the fall period. Thus, production per ha is diminished as the grazing season is extended. 
To evaluate the economic consequences of fertilizing the S/F treatment area, one scenario considered sale of stocker animals during the fall, similar to what was done in the grazing trials. Animals were assumed to be moved to an adjacent ungrazed weeping lovegrass pasture for a month during the summer. They were then reintroduced to the pasture on 27 August and grazed until the optimal sale date. This was the same rotation that was assumed with the S/F treatment with fall sale but included the additional ADG from the fertilization. Dummy variables for season of use and fertilization were appropriately adjusted for this analysis.

If stocker animals were not to be returned to the treatment area in the fall, extra forage would be available for grazing in the fertilized pastures during the spring and summer grazing periods. The stocking rate could be increased or the period of grazing extended. Thus, as a second marketing alternative for fertilized pastures, marketing in either late summer or fall (at the optimal date) without leaving the S/F $\mathrm{w} / \mathrm{F}$ treatment area was also evaluated. That is to say, for the fertilized scenario the 25 July sale date restriction was removed and stocker animals were carried to the optimal sale date. The benefits of the fertilization in this case was the extra ADG and the extended grazing period.

The economic models developed for each grazing system are spreadsheet based. The spreadsheets incorporate the assumptions about prices, costs, and production strategies as described above. Sale weights, production per ha, and net returns per ha and per animal are computed for alternative sale dates and for the specified stocking rate. The affect of declining forage quality is directly incorporated into the economic models through the specification of the ADG function and other beef production functions.

\section{Results}

\section{Livestock Response}

Continuous grazing average daily gain (ADG) was estimated to decline as a quadratic function of time (Table 3). The estimated equation shows ADG would be negative after 11 November and reach a minimum of $-0.12 \mathrm{~kg} \mathrm{head}^{-1}$ day $^{-1}$ on 10 January. The 6-Mo and 12-Mo treatments were not statistically different. The year of treatment also did not have an effect.

The ADG function of the 6-pasture rotation treatment was similar to the continuous grazing function with ADG a quadrat-

Table 3. ADG functions estimated from grazing trials and used in economic stocking rate models.

$$
\begin{aligned}
& \text { Average Daily Gain (kg/head/day) } \\
& \mathrm{ADG}=f(\mathrm{t})=1.8566-0.01547 \mathrm{t}+0.000003 \mathrm{t}^{2} \\
& (0.0496)^{\mathrm{b}}(0.00006) \quad(0.00000173) \\
& \mathrm{ADG}=f(\mathrm{t})=1.4232-0.0101 \mathrm{t}+1.0406 \text { Dfall } \\
& (0.0919) \quad(0.0015 \quad(0.1853) \\
& -0.0033 \text { tXDfall }+0.1267 \text { Dfert } \\
& (0.0018) \quad(0.0372) \\
& \mathrm{ADG}=f(\mathrm{t})=1.478-0.0117 \mathrm{t}+0.0000267 \mathrm{t}^{2} \\
& \begin{array}{lll}
(0.1131) & (0.0022) & (0.00000978)
\end{array} \\
& -0.3049 \mathrm{D} 94 \\
& \text { (0.0537) } \\
& \mathrm{R}^{2}=0.59 \\
& \mathrm{n}=742 \\
& \mathrm{R}^{2}=0.44 \\
& \mathrm{n}=602 \\
& \mathrm{R}^{2}=0.41 \\
& \mathrm{n}=345 \\
& \text { 6-Pasture Rotation }
\end{aligned}
$$

6-Pasture Rotation

ic function of time (Table 3). ADG was statistically less during 1994 as compared to 1995 and $1996\left(-0.30 \mathrm{~kg}\right.$ head $^{-1}$ day $\left.^{-1}\right)$ as indicated by the statistical significance of the 1994 dummy variable (D94). The 21-day rotation used in 1994 was too long and negatively impacted livestock performance. All economic comparisons were made with D94 set at zero.

The ADG for the S/F treatment was found to be a linear function of time. The intercept was higher and the slope steeper during the fall grazing period. Fertilizer added $0.13 \mathrm{~kg} \mathrm{head}^{-1}$ day $^{-1}$ to ADG (Table $3)$. Beef production was $19 \mathrm{~kg} \mathrm{ha}^{-1}$ more with the fertilizer application by the end of the spring grazing period on 25 July.

During the spring grazing period, the continuous grazing system was estimated to give the highest ADG, but this was at the lightest stocking rate of the 3 treatments. The ADG was $0.32 \mathrm{~kg} \mathrm{head}^{-1}$ day $^{-1}$ greater in early May for the continuous grazing system. There was no statistical difference between the gains obtained with 6-month versus 12-month continuous grazing.

With continuous grazing, beef production per ha reaches a maximum by early November when ADG reaches zero and then turns negative. The ADG did recover somewhat during the following spring, but beef production per ha remained below the November peak level. This means that to maximize profit, even if additional days of grazing were free, one would never carry stocker animals past early November, unless increasing beef prices were expected in the near future.

Because of the higher stocking rate and the improved ADG during the fall, beef production per ha would increase from a maximum of about $340 \mathrm{~kg} \mathrm{ha}^{-1}$ with continuous grazing to about $450 \mathrm{~kg} \mathrm{ha}^{-1}$ with the 6-pasture rotation system. The doubling of stocking rate with the S/F treatment would increase maximum beef production to about $560 \mathrm{~kg} \mathrm{ha}^{-1}$ if the animals were sold 25 July. If more land were allotted to carry the animals to the fall then beef production per ha would decline to below what could be produced with continuous grazing. This is because beef production is then spread over more acreage.

\section{Economic Response}

\section{Grazing System Comparison}

For the various price scenarios evaluated, the grazing system that maximized return to land and risk (RLR) varied between the continuous grazing system and the $S / F$ w/F treatment with optimal sale $^{3}$. In those years when feeder cattle prices were relatively high, and the spread between buy and sell prices was relatively narrow-years favorable for yearling stocker production-the $\mathrm{S} / \mathrm{F}$ w/F with optimal sale yielded the highest RLR. During these years a relatively high return would be made of between $\$ 35$ and $\$ 54$ $\mathrm{ha}^{-1}$ (Table 4). In less favorable price years, the continuous system was economically best, but net returns would be negative in many of these unfavorable price years and the light stocking rate of the continuous system would minimize losses. In these years at least part of the fixed costs could be covered by using the continuous grazing system.

\footnotetext{
${ }^{3}$ While the designation of "optimal sale" has been used to differentiate this treatment from the treatment with a period of pasture rest during the summer, economically optimal sale dates are in early fall. The important distinction is that in this case animals would not be removed from the $S / F$ pasture until sale at the optimal date.
} 
Table 4. Economic results for alternative stocker grazing systems.

\begin{tabular}{|c|c|c|c|c|c|c|c|}
\hline Year & Continuous & Rotation & $\begin{array}{c}\mathrm{S} / \mathrm{F} \\
\text { optimal } \\
\text { sale }\end{array}$ & $\begin{array}{l}\text { S/F with } \\
\text { fall sale }\end{array}$ & $\begin{array}{c}\mathrm{S} / \mathrm{F} \text { w/F } \\
\text { optimal } \\
\text { sale }\end{array}$ & $\begin{array}{l}\mathrm{S} / \mathrm{F} \text { w/F } \\
\text { fall sale }\end{array}$ & $\begin{array}{l}\text { Optimal } \\
\text { Grazing } \\
\text { System }^{\mathrm{a}}\end{array}$ \\
\hline \multicolumn{8}{|c|}{$\underline{\operatorname{RLR}\left(\$ \text { ha }^{-1}\right)}$} \\
\hline 1984 & 1.93 & -4.10 & -9.14 & -38.11 & -4.12 & -54.61 & 1.93 \\
\hline 1985 & -48.34 & -70.49 & -100.28 & -60.98 & -98.65 & -77.88 & -37.05 \\
\hline 1986 & 23.04 & 24.40 & 31.54 & -27.84 & 36.58 & -44.36 & 36.58 \\
\hline 1987 & 36.93 & 37.99 & 35.54 & -24.95 & 53.82 & -39.17 & 53.82 \\
\hline 1988 & -18.11 & -37.57 & -76.82 & -52.64 & -54.91 & -66.29 & -18.11 \\
\hline 1989 & 30.28 & 26.21 & 8.65 & -30.21 & 35.15 & -43.18 & 35.15 \\
\hline 1990 & 40.73 & 38.80 & 20.85 & -26.23 & 51.94 & -38.48 & 51.94 \\
\hline 1991 & -51.97 & -83.86 & -145.19 & -69.53 & -121.47 & -82.94 & -37.05 \\
\hline 1992 & 15.59 & 7.31 & -14.94 & -36.68 & 8.79 & -50.07 & 15.59 \\
\hline 1993 & 38.68 & 36.95 & 21.66 & -26.53 & 49.99 & -39.25 & 49.99 \\
\hline 1994 & -30.63 & -53.18 & -94.70 & -57.80 & -76.42 & -72.03 & -30.63 \\
\hline 1995 & -46.71 & -70.10 & -104.41 & -62.15 & -98.50 & -78.47 & -37.05 \\
\hline 1996 & -3.41 & -7.95 & -6.67 & -36.83 & -9.06 & -54.34 & -3.41 \\
\hline Average & -0.92 & -11.97 & -33.38 & -42.34 & -17.45 & -57.01 & 6.28 \\
\hline \multicolumn{8}{|c|}{ Optimal Sale Date } \\
\hline 1984 & 04-Sep & 19-Sep & 25-Jul & 05-Aug & 27-Aug & 03-Aug & 04-Sep \\
\hline 1985 & 01-Sep & 13-Sep & 25-Jul & 16-Jul & 24-Aug & 29-Jul & None \\
\hline 1986 & 04-Sep & 19-Sep & 25-Jul & 05-Aug & 27-Aug & 03-Aug & 27-Aug \\
\hline 1987 & 14-Sep & 07-Oct & 25-Jul & 18-Sep & 02-Sep & 24-Sep & 02-Sep \\
\hline 1988 & 16-Sep & 10-Oct & 25-Jul & 20-Sep & 04-Sep & 26-Sep & 16-Sep \\
\hline 1989 & 18-Sep & $15-\mathrm{Oct}$ & 25-Jul & 22-Sep & 05-Sep & 29-Sep & 05-Sep \\
\hline 1990 & 20-Sep & 20-Oct & 25-Jul & 23-Sep & 06-Sep & 01-Oct & 06-Sep \\
\hline 1991 & 18-Sep & $12-\mathrm{Oct}$ & 25-Jul & 21-Sep & 04-Sep & 27-Sep & None \\
\hline 1992 & 17-Sep & $13-O c t$ & 25-Jul & 20-Sep & 04-Sep & 27-Sep & 17-Sep \\
\hline 1993 & 19-Sep & 17-Oct & 25-Jul & 22-Sep & 05-Sep & 29-Sep & 05-Sep \\
\hline 1994 & 15-Sep & 06-Oct & 25-Jul & 18-Sep & 02-Sep & 24-Sep & 15-Sep \\
\hline 1995 & 05-Sep & 20-Sep & 25-Jul & 06-Aug & 28-Aug & 15-Sep & None \\
\hline 1996 & 30-Aug & 05-Sep & 25-Jul & 11-Jul & 21-Aug & 18-Jul & 30-Aug \\
\hline \multicolumn{8}{|c|}{ Optimal Sale Weight $\left(\mathrm{kg} \mathrm{head}^{-1}\right)$} \\
\hline 1984 & 357 & 343 & 311 & 318 & 338 & 328 & 357 \\
\hline 1985 & 356 & 341 & 311 & 305 & 337 & 324 & None \\
\hline 1986 & 357 & 343 & 311 & 318 & 338 & 328 & 338 \\
\hline 1987 & 361 & 349 & 311 & 347 & 341 & 364 & 341 \\
\hline 1988 & 362 & 350 & 311 & 348 & 341 & 366 & 362 \\
\hline 1989 & 362 & 352 & 311 & 349 & 341 & 367 & 341 \\
\hline 1990 & 362 & 352 & 311 & 349 & 342 & 368 & 342 \\
\hline 1991 & 362 & 351 & 311 & 348 & 341 & 366 & None \\
\hline 1992 & 362 & 351 & 311 & 348 & 341 & 366 & 362 \\
\hline 1993 & 362 & 352 & 311 & 349 & 341 & 367 & 341 \\
\hline 1994 & 361 & 349 & 311 & 347 & 341 & 364 & 361 \\
\hline 1995 & 358 & 344 & 311 & 319 & 339 & 358 & None \\
\hline 1996 & 355 & 338 & 311 & 302 & 336 & 317 & 355 \\
\hline Average & 360 & 347 & 311 & 334 & 340 & 353 & \\
\hline \multicolumn{8}{|c|}{ Optimal Beef Production ( $\left.\mathrm{kg} \mathrm{ha}^{-1}\right)$} \\
\hline 1984 & 327 & 423 & 548 & 280 & 597 & 288 & 327 \\
\hline 1985 & 326 & 421 & 548 & 269 & 595 & 286 & None \\
\hline 1986 & 327 & 423 & 548 & 280 & 597 & 288 & 597 \\
\hline 1987 & 330 & 431 & 548 & 301 & 600 & 315 & 600 \\
\hline 1988 & 330 & 432 & 548 & 301 & 601 & 315 & 330 \\
\hline 1989 & 332 & 433 & 548 & 302 & 601 & 316 & 601 \\
\hline 1990 & 332 & 436 & 548 & 302 & 603 & 317 & 603 \\
\hline 1991 & 332 & 432 & 548 & 302 & 601 & 315 & None \\
\hline 1992 & 330 & 433 & 548 & 301 & 601 & 315 & 330 \\
\hline 1993 & 332 & 435 & 548 & 302 & 601 & 316 & 601 \\
\hline 1994 & 330 & 431 & 548 & 301 & 600 & 315 & 330 \\
\hline 1995 & 327 & 424 & 548 & 280 & 598 & 310 & None \\
\hline 1996 & 325 & 417 & 548 & 265 & 594 & 278 & 325 \\
\hline Average & 329 & 429 & 548 & 291 & 599 & 306 & \\
\hline
\end{tabular}

"The "Optimal Grazing System" column repeats production rates and returns for the grazing system that maximizes RLR for the specified price year (as shown by boxes). If economic losses exceed the assumed fixed costs $\left(\$ 37.05 \mathrm{ha}^{-1}\right)$ then not producing at all would minimize losses and this is the indicated optimal strategy for that year.
These 2 grazing strategies are very similar. By extending the grazing season to the optimal sale date, the $\mathrm{S} / \mathrm{F}$ w/F grazing treatment is just like the continuous system, but at nearly twice the stocking rate. In fact, it is likely that the ADG differences are not the result of the grazing system but rather stocking rate differences. This is consistent with the findings of Hart et al. (1988). These authors found that 3 alternative grazing systems, including season-long continuous grazing, rotationally deferred grazing and short duration rotation, did not affect steer gains differentially when compared at the same stocking rates under proper management. It highlights that stocking rate (SR) needs to be a choice variable in the management decision.

There were 3 years $(1985,1991$, and 1995) when beef prices were such that not producing at all and losing fixed costs $\left(\$ 37 \mathrm{ha}^{-1}\right)$ would have minimized losses (Table 4). Recognizing these years obviously take perfect foresight about future market conditions. Yet, even without this foresight, some generalizations and conclusions from the analysis are obvious. First, grazing weeping lovegrass pastures with yearlings is not an economically viable alternative, but if yearlings are grazed, the optimal grazing strategy for weeping lovegrass pastures is a continuous grazing scheme whereby stocker cattle enter the pasture and remain there until being sold in early September. This would be about a month earlier then when stockers are usually sold from native rangeland in New Mexico (Torell et al. 1998). Second, if yearlings are to be produced, annual planning and analysis will be required to evaluate economic feasibility, to determine whether to fertilize the pastures, and to set the annual stocking rate. Different production strategies and stocking rates should be used each year depending on market expectations. Forward contracting could potentially be very valuable in helping reduce price risk.

The net economic benefit of fertilizing the pastures was found to be variable. When market conditions were such that relatively heavy stocking rates were most profitable, fertilizing to facilitate stocking rate increases resulted in positive economic returns. As shown in Table 4, when the $\mathrm{S} / \mathrm{F}$ w/F optimal sale was best (during the 1986, 1987, 1989, 1990, and 1993 price years) fertilization of the pasture resulted in an average RLR increase of $\$ 11.56 \mathrm{ha}^{-1}$, relative to the lightly stocked continuous treatment without fertilizer. The annual 
average percentage increase in RLR ranged from $29 \%$ to $45 \%$ during these years. However, during other years when the light stocking of the continuous treatment was economically optimal, fertilization of the pasture and management as $\mathrm{S} / \mathrm{F}$ w/F optimal sale would result in an average loss of $\$ 21.78 \mathrm{ha}^{-1}$, slightly more than the cost of the fertilizer and application.

In the grazing trials, cattle were removed from the $\mathrm{S} / \mathrm{F}$ treatment area each year near the end of July. Yet, with fertilization it was felt that the grazing season could have been extended, and the economic analysis has considered that the season would be extended to the computed optimal sale date (Table 4). The relatively heavy stocking rate and extension of the sale date to late August or early September may not be possible during some years depending on rainfall and forage conditions, but this extended grazing season is important for realizing positive economic returns from the fertilizer treatment. For the $\mathrm{S} / \mathrm{F} \mathrm{w} / \mathrm{F}$ treatment, if cattle were sold on 25 July instead of the optimal date, net returns would have been reduced by an average of $\$ 16.25 \mathrm{ha}^{-1}$ over the 1984 to 1996 period.

\section{Cropping Versus Grazing Comparison}

Average New Mexico CRP program payments have been $\$ 93.86 \mathrm{ha}^{-1}$ (Osborn et al. 1995), and the CRP clearly gave eastern New Mexico farmers a higher average rate of return than cropping alternatives. As a comparison, the CPI was used to adjust traditional dryland crop production returns, as reported in Hawkes and Libbin (1997a, 1997b) for the 1984-96 period, to constant 1996 levels. This analysis shows that with crop subsidy program payments in place, Eastern New Mexico dryland farmers had an average return of $\$ 37 \mathrm{ha}^{-1}$ in Curry County and $\$ 10 \mathrm{ha}^{-1}$ in Quay County (Fig. 1). If crop subsidy payments are removed, as they supposedly will be (USDA-ERS 1996), average returns over the 1984-96 period would have been $-\$ 14.94 \mathrm{ha}^{-1}$ in Curry County and $-\$ 25.30 \mathrm{ha}^{-1}$ in Quay County ${ }^{4}$. Positive returns would have been realized in only 4 of the 13 years in Curry County and 3 of the years in Quay County.

\footnotetext{
${ }^{4}$ This assumes no change in production practices and input use. It would be anticipated that without crop subsidies, crop supplies will decrease and prices will increase. For this to happen marginal producers must leave the business. This may well be dryland farms in the Southern Great Plains that are considered here.
}

\section{Curry County}

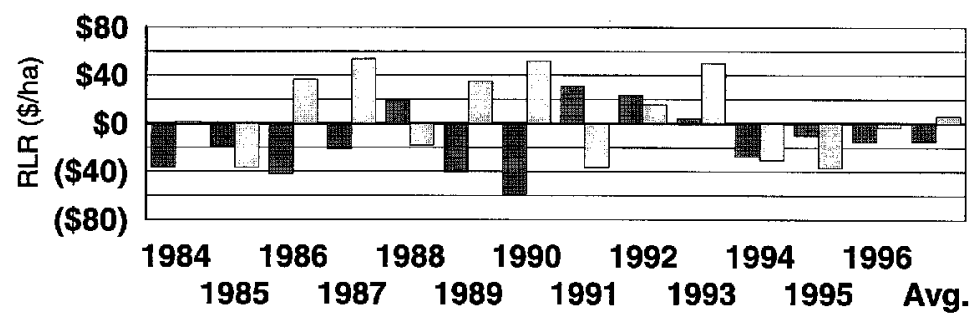

\begin{tabular}{|l|r|r|l|l|l|l|l|l|l|l|l|l|r|r|}
\hline \multicolumn{1}{|c|}{ Crop With } & 0.44 & 41.12 & 61.30 & 148.80 & 74.51 & -7.23 & -21.34 & 75.82 & 63.90 & 47.41 & -6.78 & -1.23 & 6.01 & 37.13 \\
\hline O Crop Without & -36.96 & -18.73 & -42.35 & -21.09 & 19.06 & -40.60 & -58.97 & 30.81 & 23.30 & 4.45 & -27.62 & -10.13 & -15.41 & -14.94 \\
\hline O Grazing & 1.93 & -37.05 & 36.58 & 53.82 & -18.11 & 35.15 & 51.94 & -37.05 & 15.59 & 49.99 & -30.63 & -37.05 & -3.41 & 6.29 \\
\hline
\end{tabular}

\section{Quay County}

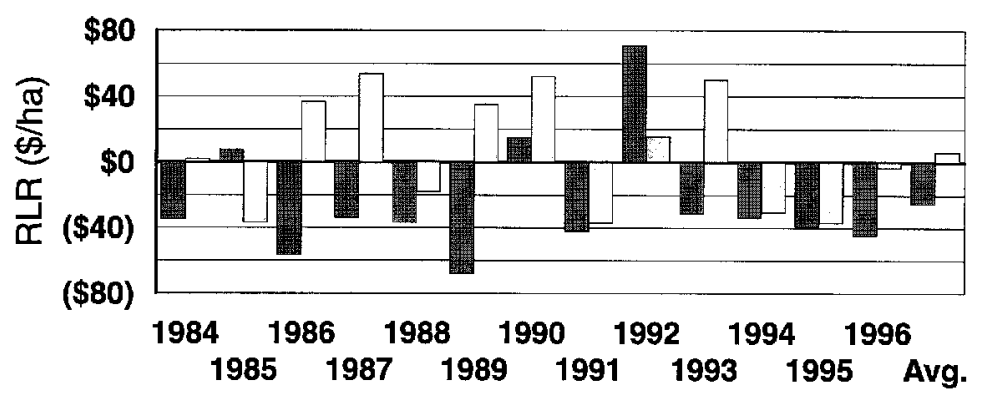

\begin{tabular}{|l|c|c|c|c|c|c|c|c|c|c|c|c|c|c|}
\hline Crop with & 2.80 & 78.70 & 14.02 & 35.75 & -18.83 & -63.50 & 75.30 & -9.57 & 107.19 & -5.87 & -18.63 & -31.05 & -35.68 & 10.05 \\
\hline T Crop without & -34.89 & 7.57 & -56.73 & -33.87 & -36.92 & -68.14 & 14.90 & -42.68 & 70.90 & -31.15 & -33.91 & -39.20 & -44.79 & -25.30 \\
\hline$\square$ Grazing & 1.93 & -37.05 & 36.58 & 53.82 & -18.11 & 35.15 & 51.94 & -37.05 & 15.59 & 49.99 & -30.63 & -37.05 & -3.41 & 6.28 \\
\hline
\end{tabular}

Fig 1. Comparison of constant 1996 RLR (\$/ha) for traditional cropping alternatives, with and without price support payments, versus grazing weeping lovegrass pastures with yearling stockers.

Dryland farming in the Southern Great Plains has traditionally yielded relatively low rates of return and removal of crop subsidies would be expected to cause major changes in land use for these dryland farming areas.

Leaving weeping lovegrass pastures in place for yearling stocker production does not appear to provide a viable economic alternative either ${ }^{5}$. Average return to land and risk (RLR) from grazing yearlings with beef prices realized over the 1984-96 period was estimated to be $\$ 6.28 \mathrm{ha}^{-1}$ if optimal production strategies were followed (Table 4). Net returns actually real-

\footnotetext{
${ }^{5}$ This is not to say that grazing weeping lovegrass pastures with other animal classes would not be economically feasible. Using lovegrass in rotation with other native grass species or as a place to maintain brood animals may be feasible but these alternatives were not considered in this research.
}

ized will likely be less because the afterthe-fact knowledge about fall sale prices, as used in the economic analysis, will not be available to farmers as they make annual production decisions. It is likely that realized net returns from grazing will be negative on average. This is similar to expectations for cropping alternatives without price supports. If the estimated average optimal RLR of $\$ 6.28 \mathrm{ha}^{-1}$ were realized this would still be less than a $1 \%$ rate of return on an approximate $\$ 494 \mathrm{ha}^{-1}$ average land investment value (personal communication, Trevor Ashby, Farm Credit Services, Clovis, N.M., 5 November 1998). Further, positive economic returns from yearling stocker production only occurred in 6 of the 13 years with optimal production (stocking rate) adjustments (Fig. 1). These stocking rate adjustments must be made to take advantage of favorable market conditions and to minimize losses during unfavorable condi- 
tions if on average RLR is to remain positive. As shown in Table 4, no one grazing system (constant stocking rate) would have yielded an average positive RLR over the 1984-96 period.

\section{Discussion}

In hindsight, the decision to plant relatively low-cost weeping lovegrass when entering the CRP program was an economic mistake. New CRP enrollment guidelines (USDA-FSA 1997) have precluded many of these lovegrass pastures from continued enrollment in CRP because they do not provide the wildlife cover and habitat desired by the extended CRP program. Cropping alternatives look dismal without continued crop subsidies, and grazing the weeping lovegrass pastures with stocker cattle does not provide a viable economic alternative either.

Under provisions of the 1996 Federal Agriculture Improvement and Reform (FAIR) Act (P.L. 104-107) federal outlays to the farm sector will decline until 2002, after which they are scheduled to be eliminated. The FAIR Act removes the link between income support payments and farm prices by providing for 7 annual fixed but declining market transition payments (USDA-ERS 1996). Farmers in the Southern Great Plains, and other areas, will receive these payments regardless of whether they crop or graze the land, provided the acreage was included under previous farm programs.

With these market transition payments, or with continued CRP enrollment, farmers have government support until 2002. However, without CRP and without crop subsidies, dryland farmers in the Southern Great Plains face an increasingly uncertain future. Farmers have historically been willing to accept rates of return on investment that are unacceptable by standard investment criteria. As a group, farmers and ranchers are optimists who always believe the next season will be a good one. This analysis shows, however, that the free market commodity pricing proposed for the future will be especially hard on dryland farmers in the Southern Great Plains.

What is the future for these lands? Some have argued that great stretches of the arid, wind-swept Great Plains are not suited to conventional settlement, and never really were. They contend that only with ever expanding crop and water subsidy programs was cropping of these marginal lands possible, and that it is now time to tear down the fences, replant native grasses and restock buffalo and other native species (Popper and Popper 1994, Matthews 1992). This research also finds that dryland farming in the Southern Great Plains is likely not economically sustainable without subsidy programs. It is widely believed that these government programs have been capitalized into land values as the continued perpetual existence of these programs came to be expected (Helmberger 1991). If elimination of these price support programs is in fact implemented, major market adjustments would be expected. Land values should fall and marginal farming areas should revert to rangeland and natural vegetation. Some believe that this transition would be desirable and that the Great Plains can provide sustainable income only by reverting to the natural rangeland vegetation and crops originally found on the prairies (Eisenberg 1989). The future use and management of these farming areas has major implications for rural communities and the people who live there.

\section{Literature Cited}

Eisenberg, E. 1989. Back to Eden. Atlantic Monthly, November:57-89.

Hart, R.H., M.J. Samuel, P.S. Test, and M.A. Smith. 1988. Cattle, vegetation, and economic responses to grazing systems and grazing pressure. J. Range Manage. 41:282-286.

Hawkes, J.M. and J.D. Libbin. 1997a. A long-term look at crop profitability in New Mexico: cost and return estimates for 19841993. New Mex. State Agr. Exp. Sta. Res. Rep. 718, Las Cruces, N.M..

Hawkes, J.M. and J.D. Libbin. 1997b. Crop cost and return estimates in New Mexico, 1995. New Mex. State Agr. Exp. Sta. Research Report 716, Las Cruces, N.M..

Helmberger, P.G. 1991. Economic analysis of farm programs. McGraw Hill, Inc., New York, N.Y.

Hildreth, R.J. and M.E. Riewe. 1963. Grazing production curves II. Determining the economic optimum stocking rate. Agron. J. 55:367-372.

Huffaker, R.G. and J.E. Wilen. 1991. Animal stocking under conditions of declining forage nutrients. Amer. J. Agr. Econ. 73:1213-1223.

Matthews, A. 1992. Where the buffalo roam. Grove Press, New York, N.Y.

National Oceanic and Atmospheric Administration (NOAA). Various Issues. Climatological data, New Mexico monthly precipitation departure from individual stations' normals. National Climatic Data Center. Asheville, N.C.

Osborn, C.T., F. Llacuna, and M. Linsenbigler. 1995. The Conservation Reserve Program: enrollment statistics for signup periods 1-12 and fiscal years 1986-93. United States Dept. of Agr., Econ. Res. Serv. (ERS) Stat. Bull. 925, Washington, D.C.

Popper, F.J. and D.E. Popper. 1994. Great Plains: checkered past, hopeful future. Forum for Appl. Res. and Public Policy. Winter '94, 9:89-100.

Sartwelle, J.D., III, J.R. Mintert, T.C. Schroeder, M.R. Langemeier, and F. Brazle. 1995. Feeder cattle price differentials: how much do they change over time? Paper presented at the Southern Agr. Econ. Assoc. Meetings, Jan. 29- Feb. 1, 1995.

Sartwelle, J.D., III, F.K. Brazle, J.R. Mintert, T.C. Schroeder, and M.R. Langemeier. 1996a. Buying and selling feeder cattle: the impact of selected characteristics on feeder cattle prices. Cooperative Extension Service, Kansas State University, Manhattan, Pub. MF-2162.

Sartwelle, J.D., III, F.K. Brazle, J.R. Mintert, T.C. Schroeder, and M.R. Langemeier. 1996b. Improving the value of your calf crop: the impact of selected characteristics on calf prices. Cooperative Extension Service, Kansas State University, Manhattan, Pub. MF-2142.

Torell, L.A., J.M. Hawkes, and T.D. Stromei. 1998. Range Livestock Cost and Return Estimates for New Mexico, 1996. New Mex. State Agr. Exp. Sta. Res.Rep.726, Las Cruces, N.M.

Torell, L.A., R.E. Kirksey, G.B. Donart, and J.D. Libbin. 1999. Economics of Cropping and Grazing Alternatives for CRP Lands in the Southern Great Plains. In: E.T. Bartlett and L.W. Van Tassell (eds). Symposium Proc. Sponsered by Western Coordinating Committee on Range Economics --(WCC55),- Soc. Range Manage. Meetings, Omaha, Neb., Feb.

United States Department of Agriculture, Economic Research Service (USDA-ERS). 1996. Provisions of the Federal Agriculture Improvement and Reform Act of 1996. Agr. Info. Bull. 729, Washington, D.C.

United States Department of Agriculture, Farm Service Agency (USDA-FSA). 1997. Fact sheet: Conservation Reserve Program sign-up 16 environmental benefits index. October. Washington, D.C.

Vallentine, J.F. 1990. Grazing management. Academic Press, Inc. New York, N.Y.

Workman, J.P. 1986. Range economics. MacMillan Publishing Co. New York, N.Y. 